\title{
Universiteit
}

Leiden

The Netherlands

\section{Religion and violence or the reluctance to study this relationship}

Cliteur, P.B.

\section{Citation}

Cliteur, P. B. (2010). Religion and violence or the reluctance to study this relationship. Form Philosophicum, 15(1), 205-227. Retrieved from https://hdl.handle.net/1887/15855

$\begin{array}{ll}\text { Version: } & \text { Not Applicable (or Unknown) } \\ \text { License: } & \text { Leiden University Non-exclusive license } \\ \text { Downloaded from: } & \text { https://hdl.handle.net/1887/15855 }\end{array}$

Note: To cite this publication please use the final published version (if applicable). 


\title{
RELIGION AND VIOLENCE OR THE RELUCTANCE TO STUDY THIS RELATIONSHIP
}

\author{
PAUL B, CLITEUR
}

University of Leiden

Abstract. This article is about the religious roots of violence, in particular religious terrorism. The author argues that there is a great reluctance to study this relationship. This is unfortunate because only on the basis of a realistic estimate of the facts can a successful counterterrorist strategy be developed. One of the problems with religious violence is that holy scriptures, in some passages, exhort believers to violent acts. In combination with a theory of ethics that is known as "divine command morality" this is problematic. Even if the holy book contains only a small percentage of passages invoking violence they pose a problem if the whole book is considered to be holy and the word of God.

\section{INTRODUCTYON}

The great scholar in Middle East-studies, Bernard Lewis, wrote: "Terrorism requires only a few. Obviously, the West must defend itself by whatever means will be effective. But in devising means to fight the terrorists, it would surely be useful to understand the forces that drive them" (Lewis, 2003 , p. xxviii).

Now, terrorists can be motivated by several factors (Guiora, 2008, p. 3). Sometimes it is about the control of a piece of land. Sometimes the aims are political in another sense. But the form of terrorism that requires much attention since $9 / 11$ is, of course, Islamist terrorism. This type of terrorism is not primarily about land or aims we would primarily identify as "political", but as "religious" in the sense that terrorists themselves present religious reasons for their terrorist acts. Although this is an unpopular statement it is perfectly true. As terrorism-expert Amos Guiora writes, "religion is certainly a primary motivator for modern day terrorists". It also seems 
true, as Lewis contends, that "Know thy enemy" must be the guiding light for any nation-state in developing operational counterterrorism policy." So if we want to take I_ewis seriously this would bring us to the aim of understanding the relationship between religion and violence. What exactly is that relation?

In this article the relationship between religion and violence will be studied, against the backdrop of the most important manifestation of religious violence: Islamist terrorism. But although Islamist terrorism is the most well known manifestation of religious violence, it can only be understood if we also inquire into the nature of the theist worldview in general. The roots of violence within Islam can only be adequately researched and understood against the background of the roots of violence in the other two theist religions: Christianity and the Jewish religion. So we should highlight not only the Koran and other Islamic sources as relevant material for our study, but the Bible (in particular the Old Testament) as well.

Although a considerable number of commentators are now engaged in studying the relationship between religion and violence, this area of interest still remains highly controversial. There is, apparently, a great reluctance among scholars and the public at large to acknowledge that there could be such a connection. Many people, and certainly not all of them religious believers, simply cannot accept that religion also has a dark and violent side. Studying the relationship between religion and violence is even considered to be rude or offensive to religious sensibilities. The strategies to explain away the manifest connections are so prevalent that they form an interesting object of study in themselves. This is also a topic of this article.

In the first section I will start with some preliminary remarks about religion and violence. Section II tries to understand why the religious roots of violence are so often overlooked, by comparing "religion" to what is dearest to us: a family member or a loved one. In section III, I will try to answer the question how we can successfully do research into the religious roots of violence. Section IV entails an analysis of the meta-ethical theory that is the basis of religious violence in the three theistic traditions: divine command morality. Section V presents us with the results of this theory in the figure of the biblical forerunner of religious terrorism (Phinehas). Sections VI and VII deal with objections that may be presented to the analysis elaborated in this article, while section VIII is dedicated to a comparison between Christianity and Islam as sources of religious violence. As will be made clear in this article my claim is that an analysis such as the one presented here should not be considered "anti-religious", nor "anti-Christian", "anti-Jewish" or "anti-Islamic", but necessary in order to make a valid con- tribution to the analysis of the contemporary roots of violence. I am not pessimistic about the possibilities of the theistic religions refraining from violence, but in order to be successful in this regard we have to know what we have to look for. In other words: only a sober, objective and balanced view of the roots of violence in the three theistic religions can be helpful in this age of religious turmoil and rising fundamentalism and fanaticism.

\section{BASSAM TIBI ON RELIGION AND VIOLENCE}

In earlier times violence and intimidation were regarded as necessary for the preservation of religion. A religious war, or the torture of a heretic or an infidel, were not considered to be morally outrageous, but necessary for the preservation of belief and ultimately the social order. This attitude is not very common nowadays, at least not in the Western world. Nevertheless, that does not mean that people take religion to task when it seems to be connected with violence. What the advocates of religion usually do, is simply deny that religion has anything to do with violence as perpetrated by e.g. terrorists (religious terrorism being the clearest manifestation of religious violence nowadays). They say: "Religion is only superficially involved in this type of violence. Terrorism is caused by exclusion, racism, personality disorders, social and economic inequality and lots of other things, but one thing is certain: this violence has nothing to do with religion." That means that the terms "religious violence" or "religious terrorism" are misnomers.

When freethinkers, atheists, secularists or simply less prejudiced commentators on religion point out what, according to their analysis, the relationship between religion and violence amounts to, the advocates of religion, in most cases, react with dismay and even indignation. How can anybody be so stupid as to not see that religion is only "superficially" connected with the behaviour we all reject? How can we fail to understand that bad men and women "misuse" religion for their own petty causes? If the critic of religion persists in his indictments, the advocates of religion usually get more impatient. They accuse him of "insulting" believers, and they even try to silence him with blasphemy laws. Terms like "religious terrorism" or "religious violence" are invented by the enemies of religion, they say, namely, by the secularists, the atheists, people who want to scoff at religion - but religion itself, many people argue, is in its very nature pure and pristine. But, as the Islam-scholar, political scientist and professor of international relations Bassam Tibi (1944-) rightly stresses when referring 
to the sociologist Mark Juergensmeyer (2003 and 2008), "Jihadism as 'terror in the mind of God' is based on 'ideals and ideas' which are 'authentically and thoroughly' religious" (Tibi, 2008, p. 98). Time and again Tibi warns us about the popular mistake of underestimating the relationship between contemporary terrorism and its roots in Islamic doctrine, because the Islamist challenge can only be met if we first acknowledge that parts of the Islamic tradition are vitiated by Islamist ideology. Tibi contends this as a Muslim and because it is necessary to separate violent tendencies from peaceful tendencies within the Islamic tradition (Tibi, 2009).

This approach is as unpopular nowadays as was once the case for the study of the Inquisition in relation to Catholic doctrine. The aim of this article is to present some prolegomena to a less biased attitude towards religion. And by "less biased" I mean an attitude that tries to understand where the violent element in religion comes from.

Let us first shoot a glance at some classic discussions about this theme in the past.

\section{CAN A FATHER CONCEDE THAT HIS DAUGHTER COMMITTED HOMICIDE?}

One of the most important historical documents on the subject of religion in relation to morals is a dialogue by Plato: the Euthyphro (Taylor, 1977). This starts with a dramatic scene. Euthyphro has just deposed murder charges against his own father for the death of a servant. Prosecuting your own father on such a charge is quite uncommon and Socrates seems very surprised: "Good heavens!

(. . .) Euthyphro, most men would not know how they could do this and be right" (Plato, Euthyphro, 4a). Socrates further inquires: "Is then the man your father killed one of your relatives? Or is that obvious, for you would not prosecute your father for the murder of a stranger." Now Euthyphro is shocked:

It is ridiculous, Socrates, for you to think that it makes any difference whether the victim is a stranger or a relative. One should only watch whether the killer acted justly or not; if he acted justly, let him go, but if not, one should prosecute, if, that is to stay, the killer shares your hearth and table (Plato, Euthyphro, 4c).

From a perspective of abstract justice Euthyphro may be right. But at the same time it seems realistic to suppose that not all of us would act in accordance with his high morals.
Suppose there is a father who has a lovely daughter of eighteen years. Not a very difficult state of affairs to imagine, of course, because many daughters are lovely in the eyes of their fathers.

On a gloomy day the police arrive at the front door of this father. What has happened? The police inform him: "Your daughter has committed a very serious crime: homicide." What would be his reaction?

Every father's first reaction will be one of indignation and disbelief. This cannot be true. The people accusing his daughter - bystanders, the police, the whole world - must have made a terrible mistake. Why? Because his daughter is no murderess, of course. Every loving father knows that for sure. So his state of disbelief automatically transforms itself into a state of denial.

Now let us take the step to religion. What do religions have in common with daughters? Every believer knows for sure that God is love, and religion is the most holy thing in the world. That is also the reason why the believer is a believer in the first place. Now there are strange people who suddenly come up with stories about the violent aspects of religion: scientists, scholars, freethinkers, secularists, atheists, critics of religion. Their accounts cannot be true. They must be prejudiced by their negative attitude towards the holy creed. "If my religion had a violent tendency then I myself would be a potential criminal", the believer will tell us. This is too absurd even to contemplate.

And so the loving father (or loving husband) and the true believer will never accept that their favourites are in any way implicated in gross violence or other atrocious acts. As philosopher Brand Blanshard wrote:

Next to romantic love, religion is the area of human life where reason is most easily swept away. Against faith, reason has little chance with the great majority (Blanshard, 1984, p. 105)

Yet there are also differences between fathers and true believers. In the state of denial that both share, the father is in a less fortunate position than the true believer. That has to do with the nature of reality. Daughters are humans, that is: physical entities. So homicide, as punishable by law, is also something that can be empirically verified. And that means the loving father, although reluctantly, has to face the facts if the evidence is as strong as the police contend, especially if corroborated by the judge.

The situation of the true believer in his state of denial is more promising. That has to do with the nature of religion. Religion is not - as daughters are - something that can be empirically perceived. Religion is something mental, not a spatiotemporal thing. Religion is something mental, 
because ideas are mental. So whether the motives of religious terrorists are truly "religious" is a matter of interpretation. And for the true believer, so it seems, there are always routes of escape. He can always (and will often) say: "it was not religion, it was culture, social position, mental condition and many other things", but not religion that was the cause of the trouble.

This attitude was aptly formulated by the philosopher Herbert Spencer (1820-1903), himself an agnostic, when he said:

The truly religious element of Religion has always been good; that which has proved untenable in doctrine and vicious in practice, has been its irreligious element; and from this it has been undergoing purification (Spencer, 1995, p. 3).

So religion is good, according to Spencer. What seems bad in religion is simply "irreligious".

Of course, numbers count. You cannot say a religion is violent because only a few believers make a totally unwarranted connection between their criminal behaviour and their religion. But if during the $16^{\text {th }}$ and $17^{\text {th }}$ century witches, heretics and infidels were burnt at the stake and religious and political leaders adduced theological reasons provided by scripture, you cannot say: "this has nothing to do with religion". In those days Christianity was a violent religion. Because nowadays witches, heretics and infidels are not burned anymore, we should say that contemporary Christianity is much less violent than its predecessor in the $16^{\text {th }}$ and $17^{\text {th }}$ century. But what we should not do - as the apologists of religion want us to do - is say that because nowadays Christianity has lost many of its violent characteristics the violence perpetrated in earlier times had nothing to do with religion.

To substantiate my claim, let us turn back to the quote from Spencer. Suppose we substitute the word "capitalistic" for "religious" and "capitalism" for "religion". What would be the consequence? In that case we would get a sentence like the following:

The tuly capitalistic element of Capitalism has always been good; that which has proved untenable in doctrine and vicious in practice, has been its "uncapitalistic' element; and from this it has been undergoing purification.

Someone saying this would be laughed out of court. Political ideologies, like life- and worldviews, have a social aspect that may and must be evaluated, everybody would tell us. Why should we make an exception for religion?

There may be a good reason for this. That reason could be that a religious worldview differs structurally from all other worldviews. And that difference (we have to emphasise this) has to be relevant to underpin the norm that religious worldviews should be exempt from criticism whereas non-religious worldviews can be evaluated in the light of the behaviour of their adherents and the character of their basic doctrines. Such argumentation may be possible. We should never exclude the possibility that someone presents us with a spectacular analysis (it surely would be) making exactly this point. As long as this is not the case, however, we have reasons to be sceptical and there is reason to critique the attitude that Spencer advocates and is being taken for granted by so many people.

\section{HOW TO DISCOVER A RELATIONSHIP BETWEEN RELIGION AND VIOLENCE}

How can this dispute about the relationship between religion and violence be solved? Can it be solved at all? Or will this always remain a matter of opinion, reflecting the personal life stances of the disputants? There are at least two ways, so it seems, to discover if there is such a relationship and, if so, what its nature is

The first "research-strategy," for inquiring into this matter could be: to look whether a certain religion is in possession of a revealed holy book on which the adherents of that religion base their beliefs and moral behaviour. This is indeed the case with the Jewish, Christian and Muslim religions. The so-called "theistic faiths" are "religions of the book". Those religions have a special relationship with three books that reveal the truth about God's wishes with regard to mankind. Those books are: the Old Testament, the New Testament and the Koran. The Old Testament is the most important book for the Jews. The New Testament is of paramount importance for Christians. The Koran, last but not least, is the Holy. Book for Muslims.

Whoever wants to verify whether religion (or a religion) condones or even stimulates violence should consult those books and try to ascertain whether (and under what circumstances) violence is permitted or even encouraged in the texts. Once this study is undertaken, perhaps backed up with the relevant literature on religion and violence, such as the books Sacred Fury by Charles Seelengut (2003) or a book with the ominous title Is Religion Killing us? by Jack Neison-Pallmeyer (2003), every reader will see that there is much more in the holy writ than just the Sermon on the Mount.

I will not back up this contention with the many passages that are elaborately expounded on and analyzed in works by authors like Nelson- 
Pallmeyer, Seelengut, Sam Harris (2005), Shadia B. Drury (2004), Joseph Hofmann (2006), Christopher Hitchens (2007), James Haught (1995, 1990) and many other commentators.

It suffices to illustrate this point with some remarks on only two passages from holy books: one from the Koran, the other from the Bible. I will start with the youngest revelation: the Koran.

In the Koran (24:2) there is a passage on adultery and formication. The passage runs as follows:

The woman and the man guilty of adultery or fornication, flog each of them with 100 stripes: Let no compassion move you in their case, in a matter prescribed by Allah, if you believe in Allah and the Last Day.

This passage was the subject of a discussion, in the Eastern and Western world, concerning a 20-year-old woman from Qatif, Saudi Arabia, reported to have been abducted by several men and repeatedly raped. Judges found that the victim was, herself, guilty. Her crime is called "mingling". When she was abducted the woman was sitting in a car with a man not related to her by blood or by marriage. This is illegal in Saudi Arabia. She was sentenced to 200 lashes with a bamboo cane (Hirsi Ali, 2007).

This sentence will be described by many people as draconian, outrageous or unjust. Why is the woman sentenced in this harsh way? Because the Saudi law prescribes this sentence for this specific offence. But why is the Saudi law so cruel in this matter? The reason is obvious: because this penalty is prescribed in the Koran.

The Koran is not the only Holy Book that provides compelling reasons for a very harsh - by contemporary standards - treatment of offenders of the law. A good place to start our argument on the scriptural foundations of violence in the Bible is with Deuteronomy 13: 1-3 ("a warning against idolatry", as the English Standard Version euphemistically puts it). There we find the following passage:

If a prophet or a dreamer of dreams arises among you and gives you a sign or a wonder, and the sign or wonder that he tells you comes to pass, and if he says, "let us go after other gods", which you have not known, "and let us serve them", you shall not listen to the words of that prophet or that dreamer of dreams.

The attitude exemplified in this passage cannot come as a shock to a well-informed reader. Every faith will discourage its devotees from going after other gods. Every religion tries to keep its community together and so does the Jewish religion. The Bible says: "You shall walk after the Lord your God and fear him and keep his commandments and obey his voice, and you shall serve him and hold fast to him" (Deut. 13:4-5).

\section{DIVINE COMMAND MORALITY AND THEISM}

The theory of ethics that is implicit in this passage is what has been called the "divine command theory" of ethics (Idziak, 1979). It holds that the believer is supposed to follow the ethical injunctions that are revealed by God, manifested in Scripture. There is a problem though. Doing this can imply tensions with what we consider morally appropriate or what is legally required or forbidden by civil law or "human law" (as contrasted with "divine law"). This is e.g. the problem that Abraham faces when ordered by God to sacrifice his son (Genesis 22).

So far, Deuteronomy has suggested nothing that can be considered problematic in the sense of violating the moral or civil law, but in Deuteronomy 13:5 there is a turn. After the turn, we read:

But that prophet or that dreamer of dreams shall be put to death, because he has taught rebellion against the Lord your God, who brought you out of the land of Egypt and redeemed you out of the house of slavery, to make you leave the way in which the Lord your God commanded you to walk. So you shall purge the evil from your midst" (Deuteronomy 13:5-6).

So the prophet or the dreamer of dreams "shall be put to death".

If this is interpreted as a description of what will happen after death, this text may still be compatible with contemporary civil and penal law for these are only applicable to the situation here on earth. It is not very polite perhaps to tell other people that they will burn in hell for what they believe or not believe, but as long as the furnace is not ignited in this life these visions about what happens in the hereafter do not have to give us great worry. It appears from the context, however, that the Bible is not simply making a factual statement about what will happen to our souls in a future life, but admonishes the believers in this world to execute the false prophet or the "dreamer of dreams" among the living. That means: the individual believer is exhorted - in contemporary jargon - to "take the law into his own hands" and purge the community of false prophets.

That the Bible takes this point seriously is clear from further commentary on the way this prescript should be interpreted. There it appears that this injunction is not restricted to unknown people but should also be applied to those most intimate and dear to us. Our brother, our son, daughter, wife or friend - they should all be put to death if they preach rebellion against the Lord. In Deuteronomy 13:6-12 we read:

If your brother, the son of your mother, or your son or your danghter or the wife you embrace or your friend who is as your own soul entices you secretly, 
saying, "let us go and serve other gods", which neither you nor your fathers have known, some of the gods of the peoples who are around you, whether near you or far off from you, from one end of the earth to the other, you shall no yield to him or listen to him, nor shall your eye pity him, nor shall you spare him, nor shall you conceal him. But you shall kill him. Your hand shall be first against him to put him to death, and afterwards the hand of all the people.

You shall stone him to death with stones, because he sought to draw you away from the Lord your God, who brought you out of the land of Egypt, out of the house of slavery. And all Israel shall hear and fear and never again do any such wickedness as this among you.

"Warning against idolatry" is an unduly euphemistic qualification of what we find here, so it appears. It is a warning to idolaters, false prophets, and dreamers of dreams, but the text also spells out in no uncertain terms what has to be done with them. They deserve the death penalty. And the execution of this death penalty is not reserved for God in the hereafter, but the text proclaims it to be the specific duty of all members of the Jewish tribe to execute this death penalty.

Furthermore, we should not be distracted from our religious duties when the false prophet is our son, our daughter, brother or wife. Especially when it comes to those dear to us: we should be the first to throw the stone, the rest of the community has to follow.

In modern terminology we should qualify this as a prohibition of apostasy (Zwemer, 1924; Ibn Warraq, 2003; Jami 2007; Ahadi, 2008). When we compare this provision in the Bible with modern constitutions and modern text-books of penal law there is a manifest contradiction. Modem constitutions and treaties on human rights proclaim the freedom of religion. That freedom also comprises the freedom to reject one specific religion or relinquish all religions. This is stated clearly in art. 18 of the Universal Declaration of Human Rights (1948):

Everyone has the right to freedom of thought, conscience and religion; this right includes freedom to change his religion or belief, and freedom, either alone or in community with others and in public or private, to manifest his religion or belief in teaching, practice, worship and observance" (italics added; PC).

So here we have a manifest contradiction between modern constitutional texts such as The Universal Declaration of Human Rights and "Holy Scripture" as handed down by the ancient religions of the book.

That contradiction is not restricted to the matter of apostasy. The text in Deuteronomy also has a completely different opinion about taking the law into your own hands than the modern state does. Deuteronomy presents no guiding rules for how an earth-bound government has to deal with the matter of apostasy; it does not even refer to God. It is the individual member of the community who is assigned to be law officer and executioner. We all have to stone the apostates and those inciting others to embrace the false gods ourselves.

Obviously, this would be detrimental to civil order and to the principle of free speech. And this would not only be detrimental to the modern civil order, by the way, but it would also have undermined ancient states and communities. No state, whether ancient or modern, can condone violence perpetrated by citizens themselves (Weber, 1966, p. 27). We find a clear example of what this would imply in the biblical story of Phinehas.

\section{THE STORY OF PHINEHAS: BIBLICAL TERRORISM}

The story of Phinehas is told in the book of Numbers. Numbers 25 is dedicated to Baal Worship at Peor. While Israel lived in Shittim, the people of Israel began "to whore with the daughters of Moab", the Bible informs us. These invited the Israelites to the sacrifices of their gods, and those "daughters of Moab" apparently had considerable success with their invitations because the Israelites "bowed down to their gods" (Numbers 25: 2). The Bible spells out what this means: "So Israel yoked himself to Baal of Peor".

This made the Lord angry. He directed himself to Moses and said: "Take all the chiefs of the people and hang them in the sun before the Lord, that the fierce anger of the Lord may turn away from Israel."

Moses took action and said to the judges of Israel: "Each of you kill those of the men who have yoked themselves to Baal of Peor."

It is not so clear whether Moses' last command is identical to what the Lord commanded. The Lord seemed to exact the killing and punishment of all the chiefs. Moses, though, seems to build in a proviso: he ordered the killing of only those who had actually yielded to the temptation of the daughters of Moab. So for Moses a precondition for punishment was personal guilt (mens rea). From a modern perspective this seems almost selfevident, but not everybody in the community was satisfied with the way Moses handled the matter. There was a certain Phinehas who defied Moses' authority and took the law into its own hands. The immediate occasion for this was the following.

Phinehas saw how one of the men of Israel brought a Midianite woman to his tent. (Numbers 25: 6). When Phinehas saw this, he rose and left 
the congregation and took a spear. He "went after the man of Israel into the chamber and pierced both of them, the man of Israel and the woman through her belly" (Numbers 25: 8).

So far, we only have an exciting, although gruesome, story. What makes the story interesting, however, is the Lord's reaction. What did God say about Phinehas slaying the people who, according to modern standards, were perfectly justified in praying to gods of their own choosing ( since they are protected by the freedom of religion, after all)? The Lord sided with Phinehas and Moses' authority was clearly defied on the basis of the subsequent events. The Lord said to Moses: "Phinehas the son of Eleazar, son of Aaron the priest, has turned back my wrath from the people of Israel" (Numbers 25: 10). Phinehas was even rewarded for the man and woman's public execution without trial. The Lord said:

Behold, I give to him my covenant of peace, and it shall be to him and to his descendants after him the covenant of a perpetual priesthood, because he was jealous for his God and made atonement for the people of Israel (Numbers 25: 13).

So those who flout the legitimate authority of the temporal leaders of the people (Moses) are rewarded by God. Apparently, Phinehas' religious zeal is appreciated more by God than Moses' cautious way of dealing with the matter. This stance can have (and is likely to have) grave consequences. This can be seen as substantial encouragement to those who claim special knowledge of God's will and are prepared to perpetrate violence in defiance of the traditional political leaders of the state. Phinehas can be seen as the archetypical religious terrorist. Phinehas is prepared, on religious grounds ("I know what God wants") to use violence against citizens of the state, thereby violating the law of the state and defying legitimate authority. That is the essence of the religious terrorist. As Amos Guiora rightly states: "terrorism is the conflict between nation-states and non-state entities" (2008, p. 4). Phinehas was such a non-state entity. Yigal Amir was another. When Yigal Amir killed Yitzak Rabin in 1995 on the basis of religious considerations, or when contemporary Islamist terrorists kill or intimidate people because their victims are accused of "blasphemy" (cf. the Danish cartoonists or the Dutch writer Theo van Gogh) this all adheres to the same pattern. The religious terrorist wants to "punish" or intimidate the blasphemer and instil fear into the hearts of the citizenry.

What makes the story both interesting and disconcerting at the same time, is the fact that Phinehas' ruthless behaviour is more appreciated by the Lord than the way Moses had handled the matter. After all, Phinehas brought the people of Israel back on the right track, the Bible tells us. The people of Israel are expected to serve one God and one God only: the Lord. In the Ten Commandments this is put thus: "You shall have no other gods before me" (Exodus 20:3).

It is clear that this attitude and the whole worldview connected with it is hard to reconcile with modern freedom of religion, freedom of worship, freedom of speech, freedom of conscience, free inquiry and other fundamental rights ingrained in the concept of liberal democracy. It is, of course, possible to acknowledge the prohibition of venerating strange gods as a private religious command, but the state cannot act upon this political morality without violating modern human rights.

\section{BIBLICAL VIOLENCE AND MODERN LEGAL PRACTICE}

The problem with Holy Scripture (used as a comprehensive term for the Koran and the Bible as well) is that - at least when taken in a literal way it fails to educate citizens. It defines people as members of a religious community. It tells them that their highest moral commitments are those formulated by their own god. As long as the moral injunctions of the religious community are the same as the laws and morals of the national community the inherently problematic nature of this point of view is obscured, but once they diverge a problem arises. What should the sincere believer do? What precepts should he follow? Here we have the essence of the religious believer's problem. And this problem is clearly described and also provided with a solution (although it may not be "our" solution) in the biblical and Koranic stories. The primary moral responsibility of man is towards his religious community or - what amounts to the same - to his God.

Although contemporary states in the western world are not directly based on religious Scripture they have been developed against the background of theistic culture. And that makes them vulnerable to the type of logic that inheres in the great theistic creeds. Not only is Sura 24:2 influential in contemporary Saudi Arabia but Deuteronomy 13 also has some bearing on the actual course of events in this world. Compared to the passage from the Koran, the passage from Deuteronomy probably has less influence in, e.g., a Western country than Sura 24:2 has in Saudi Arabia. There are no Christian states (the United States of America, for instance) or Jewish states (Israel, for instance) where the freedom of religion is curtailed on the basis of Deuteronomy 13. But let us phrase the question slightly differently: is it likely that Deuteronomy 13 still manifests a certain influence on our penal 
law, for instance in clauses about blasphemy? If phrased in this way, the answer is probably affirmative. The Dutch penal code still has a provision for blasphemy in article 147 (which the government has indicated it wishes to abolish within the foreseeable future while at the same time extending the ambit of another article that penalizes incitement to religious hatred).

This article is almost a dead letter because the Central Prosecutors Office is not very active in bringing cases of blasphemy before the court. But the possibility still exists and this has something to do with the religious past of Europe. So Deuteronomy 13 (and other passages) certainly had influence on the suppression of freedom of speech and freedom of religion in the world of Christianity, although that influence was much more pervasive in the $16^{\text {th }}$ and $17^{\text {th }}$ centuries than it is now. From 1559 until 1966 the Catholic Church upheld the Index librorum prohibitorum. Until 1820 the Inquisition was active and deterred many dissidents from heterodoxy and heresy. Should we say that those practices were not in any way related to Christian Holy Scripture? Is there no relationship between passages such as Deuteronomy 13 and the Inquisition? That is hardly credible. Jesus says: "And if your right hand causes you to $\sin$, cut it off and throw it away. For" it is better that you lose one of your members than that your whole body go into hell" (Matth. 5:30). Once we identify society with the "body" and the individual with the "hand" the suggestion arises that the heretic should be eliminated from society in order to forestall the perdition of the whole community, precisely as was advocated in Deuteronomy 13.

Of course, other interpretations are possible. But that is not the point. The point is that an interpretation such as I have presented here is not ludicrous, and this is the way this passage has been interpreted in the past. We may like to forget this, but that is not a sensible course to follow. In a time when radicalism is on the rise we have to be prepared that some religious believers may present such radical interpretations.

There is probably the same relationship at work here as between the flogging of women in Saudi Arabia and Sura 24:2. Again, religion does not exist "per se", as a metaphysical entity in a transcendent realm of ideas, but is a social force that acts on the morals, politics and judicial system of its believers.

Many apologists for religion, especially of the liberal brand, vehemently deny this. Any supposed relationship between the actual suppression of freedom of conscience and freedom of religion and the scriptural passages manifesting the same attitude (Deuteronomy 13) is denied. Those practices are "cultural", but have nothing to do with religion as such. But we may wonder whether the apologists for religion are not simply fooling us and themselves as well. If believers declare their Scripture to be "holy" it is very likely that they really mean what they say: "holy". And one of the consequences of this is that they consider the content of their Holy Scripture as relevant for their ethical convictions.

Although that insight is not very popular, this should not scare us off. The only thing that should guide us is the truth.

That ideal should be pursued not only because of the loftiness of the ideal in itself but because an effective reformation of religious thought can only be accomplished on the basis of a realistic estimate of what the problems are.

\section{THE BOOK OF HISTORY}

In the previous pages we have been concerned with revealed Scripture as a source of information about the characteristics of a religion. But, as I have said before, a religion is not only what is "in the books". It is also what manifests itself in history. That is why we should not only read from the "book of revelation" but also from the "book of history". In other words, we have to read Joseph Hoffmann on The Just War and Jihad if we want to be informed on "violence in Judaism, Christianity \& Islam", as the subtitle of his book reads. Or we must consult Efraim Karsh on "Islamic Imperialism" (2006).

It is only those books that can give us an idea of the connection between religion and violence. The major problem, however, is not that these books are contested, but that they are ignored by many people. The vast majority of people reading about religion prefer to read literature that places religion in the most favourable light, such as the books by Karen Armstrong (2007).

Assessing the violent aspects of religion does not rule out, of course, that religion has stimulated many positive developments in world history. The American Declaration of Independence starts with the ringing words: "We hold these truths to be self-evident, that all men are created equal, that they are endowed by their Creator with certain inalienable rights" (italics are mine; PC). Here we find the basis for the American system of law: all men are created equal. The drafters of the Declaration state that because of this status as a creature of God, the human being is in possession of inalienable rights. This is a great idea! Every single human being is the bearer of certain fundamental rights that cannot be denied by the government. This idea changed the whole course of history and, we can safely say, this was 
a change for the better. Pragmatists might say: "You see? The idea of God as a creator is very useful. It brought us the idea of inalienable rights." This pragmatist is right, to a certain extent. But we can, of course, also consider the question whether it would be possible to defend the idea of inalienable rights without the idea of a Creator. Is that possible too? If the people in 1776 accepted inalienable rights as a gift of God, does that imply that we, living in the $21^{\text {st }}$ century, still have to believe in the same connection to sustain the notion of human rights for the future? Or can we adopt inalienable rights and proclaim our own non-theistic foundation?

This is important, because, as we have seen in this chapter, religion has an evil side that ought to be criticized. The attempt to argue that the evil sides of religion are simply "not religious", as Herbert Spencer and many others have done, is simply not convincing. Religion has to be subjected to criticism because only when this is accomplished can religion be purified of its nastier aspects.

Religious criticism should be fair, but straightforward. Limiting religious criticism within the confines that liberal interpretation wants to acknowledge is not enough. If we maintain the myth of authoritative scripture, as even the "moderate" or "liberal" believers do, we will make little progress.

\section{THE TWO BOOKS ARGUMENT}

One of the things that make theism problematic is that theism is easily interpreted as the doctrine that a personal god exists who has revealed his will in Holy Scripture, which must be followed no matter what the consequences will be. I have illustrated this by referring to some examples derived from two important holy scriptures: the Koran and the Bible. The first example was Koran 24:2 stating that an adulterer and an adulteress shall each be punished by whipping. A second example was a text from Deuteronomy 13:5-6, indicating that a prophet seducing the people of Israel to adore strange gods should be put to death. The example from the Bible was backed up by another passage from the Bible, but this time a "story": the story of Phinehas, as told in Chapter 25 of the book of Numbers. Phinehas is an interesting figure, because he murdered two people (one of his fellow Israeli men and one woman from a different tribe) who he deemed guilty of adoring false gods (i.e. not the god of Israel). And the legitimate authority, Moses, did not act in accordance with what Phinehas thought should be the appropriate reaction: a swift and extra-legal execution. So Phinehas took the law into his own hands and executed what he thought was the only appropriate punishment: killing the people who had violated the law of God. We have also seen that the Lord, according to the story, did not disapprove of what Phinehas had done but that he was even rewarded.

With the story of Phinehas I have tried not only to demonstrate that Holy Scripture sometimes advocates atrocious acts (which could be illustrated by other examples as well), but to give an idea of what could be called a "religious terrorist". A religious terrorist is someone who defies the legitimate authorities of the state, does not acknowledge the law of the state, and, based on Scripture, draws his own conclusions, even if these are radical indeed.

The common reaction to the line of argument set out in this article is that of the group of people who think religion has no real influence on what happens in the world. Those people will say that it is no problem that sometimes old books tell strange stories or advocate misdeeds because no sensible person would take these stories seriously. This group is composed of believers and unbelievers alike. Why unbelievers tend to think along these lines is clear: unbelievers tend to underestimate the importance of Holy Scripture. They are unbelievers, after all. They find it difficult to understand that people are seriously convinced that mingling should be punished by lashes simply because this is prescribed in an old book. And that people should be killed because they have changed from one religion to another ("Take all the chiefs of the people and hang them in the sun before the Lord", as prescribed in Numbers 25 ) will be considered by many people as utterly repulsive. Also, taking the law into your own hands and executing these cruel prescripts, as Phinehas did, is beyond the wildest dreams of most moral agents. But here comes my point: this is in fact so far beyond the wildest dreams of ordinary people that they tend to think that nobody can take Scripture seriously if it prescribes immoral deeds. And so they are not worried at all by draconian measures as prescribed in Scripture. They belittle the significance of this by telling us that it is only a "matter of interpretation". Or, they will tell us that the overwhelming majority of believers are not inclined to perpetrate immoral acts on the basis of Scripture. The conclusion they draw from this fact is that because numerically the extremists are such a small group we should not worry too much about those stories, which are considered to be "just stories" or "just texts".

What can we say of this? In fact, this argument has already been answered. I have shown that Sura $24: 2$ certainly has a modicum of influence in some places in the world (to phrase it very cautiously). There are places in the world, for instance, where Sura $24: 2$ is even more important than 
the law of the land. That is because the law of the land should always be interpreted against the backdrop of Sura $24: 2$ or, if it contradicts Sura 24:2, the law is considered illegitimate.

That brings me to a third objection. There will be people who argue as follows: "All right, you made your point with Sura 24:2, but with the biblical passage from Deuteronomy and the story of Phinehas you were less convincing." This group will point out that there is a "great difference" between the Koran and the Bible. They are both called "holy books" and at a superficial level there are some similarities, but the differences are greater than the similarities. And these differences are especially important for the matter of religious violence.

There is a host of differences that one can refer to, and my list of these disparities will not be exhaustive, but sufficient to understand what the matter is all about.

It may be possible to say: "The Bible is not one book, but two. And the second book, the New Testament, has mitigated the stern passages from the first book, the Old Testament." It is clear that Christians especially (and not orthodox Jews) will be likely to refer to the "two-books-argument". So as a reaction to the story about Phimehas in the Old Testament it may be possible to point to Romans 13 from the New Testament. There we read: "Let every person be subject to the governing authorities. For there is no authority except from God, and those that exist have been instituted by God. Therefore whoever resists the authorities resists what God has appointed, and those who resist will incur judgment" (Romans 13: 1-3). This seems a good answer to the "anarchistic" story of Phinehas who rebelled against the legitimate authority of Moses. If Phinehas would have read Romans 13 he could have known that he should not have resisted the authority of Moses who was governing him.

It would also be possible perhaps to point to the well-known passage on Caesar and Christ. Matthew 22:21 formulates it as follows: "Therefore render to Caesar the things that are Caesar's, and to God the things that are God's." In taking this passage as our point of departure and not Romans 13, it might be possible to argue, perhaps, that Phinehas was a kind of "spiritual authority" and that Moses was the worldly leader. Phinehas should not have claimed such a worldly affair as the administration of earthly justice. That is the province of Moses. Phinehas should only have proclaimed that the Israelites who prayed to the wrong gods forfeited their place in heaven or became fit for some punishment in the world hereafter. But by claiming worldly power he violated the principle of the separation of church and state that Jesus Christ so notoriously inaugurated.
A second difference between the Bible and the Koran that is often referred to is that the Bible does not speak directly to people in this time. Its message is, so to speak, much more indirect. To substantiate that contention one can, again, refer to the story of Phinehas. This is a story. And stories have to be interpreted. The Bible does not tell contemporary Christians or contemporary Jews that they should now kill all the apostates or those who want to change from one religion to another. The story from Deuteronomy tells us something about Jewish history. And perhaps not even that.

The same could be said about the story of Abraham. This is nothing more than a story. God did not address every reader but only Abraham, just this specific person in a very speciffc situation. It is impossible to draw general conclusions from this.

Is this a convincing argument? I do not think so. The story of Abraham has an unmistakably moral purpose and - I am afraid - the story of Phinehas does as well. But even if we insist on denying this, there is still the question of whether that denial is relevant. Because whatever the case may be: extremists will read the stories as having moral significance.

A third difference between the Bible and the Koran that some people present is that we have to take the attitude of the believers into account as well. There may have been one Yigal Amir killing one Yitzak Rabin whilst referring to a divine mission. But if that is the Jewish counterpart of the Islamist suicide bomber, the example of Amir dwindles into insignificance compared with the examples from the Islamist tradition.

A fourth response coming from this third group will be that they will point out that the Bible is mitigated by many other books and commentaries. If we want to understand the Torah, we have to read the Talmud as well. And the Talmud will teach us how to interpret the Torah. Once we engage in this type of study it will be clear why Jewish terrorism pales in comparison with Islamist terrorism. ing?

What could be our reaction? Isn't this type of criticism fairly convinc-

I beg to disagree. Actually, those thinking along these lines have missed the gist of the argumentation that has been developed here. I am not engaged in a kind of empirical study about the dangers of respectively Islamist, Jewish and Christian terrorism. What I try to understand is religious terrorism as an important manifestation of religious evil. That the actual danger this religious terrorism poses in some varieties of theism is much greater than in others is true, but at the same time it is irrelevant. I side with Bernard Lewis and other commentators in contending that the similarities between the three theistic faiths on a doctrinal level are important for our 
analysis, even if the actual manifestations in terms of vulnerability to terrorist influences differ significantly (Lewis, 2003, p. 4).

What about the "two books-argument"? Isn't it clear that there is a difference in character between the Bible and the Koran? There may be an element of truth in that, but the question is whether it is relevant. At least, we should not overestimate the importance of this difference. The Koran is composed of many suras. Those suras are commonly divided into the suras from the period of Mecca and the suras from the period of Medina. Those critical of Islam usually say that the Medina suras (usually more inclined to condone the harsh practices that pose a problem to modern liberal democracies) have abrogated the harsher Meccan suras. But the apologists answer that we should go back to the more "original" Meccan period to find "pure Islam".

The second point mentioned before, viz. that the story of Phinehas is a "story" is true, but it is a story with an unmistakably clear message. So I do not agree with Robert Spencer who writes that the traditional understanding of the Koran is "far beyond the biblical idea that God inspired human authors. Allah dictated every word of the Qur'an to the Prophet Mohammed through the Angel Gabriel. Allah himself is the only speaker throughout the Qur' an, and most often he addresses Muhammad, frequently telling him what to say to various adversaries" (Spencer, 2003, p. 127). In my view Spencer underestimates the similarities between the three theistic faiths.

The problem is that if Holy Scriptures are, indeed, considered "holy" and they contain only a small percentage of passages that incite violence, those scriptures can still cause much harm. I already quoted Bernard Lewis who said: "terrorism requires only a few" (Lewis, 2003, p. xxviii). He referred to the fact that we only need a few firm believers who are prepared to do the dirty work. But we can also say: "terrorism requires only a few passages in the holy book". If the holy book contains only a small percentage of passages invoking violence they pose a problem if the whole book is considered to be holy and the word of God.

\section{REFERENCES}

Ahadi, Mina, (mit Sina Vogt), 2008, Ich habe abgeschworen: warum ich für die Freiheit und gegen den Islam kämpfe, München: Heyne.

Armstrong, Karen, 2007, The Bible: The Biography, London: Atlantic Books.
Blanshard, Brand, 1984, Four Reasonable Men: Marcus Aurelius, John Stuart Mill, Ernest Renan, Henry Sidgwick, Minddletown, Connecticut: Wesleyan University Press.

Drury, Shadia B., 2004, Terror and Civilization. Christianity, Politics, and the Westem Psyche: Palgrave, MacMillan.

Guiora, Amos N., 2008, Fundamentals of Counterterrorism, Austin/Boston/Chicago/New York/The Netherlands: Wolters Kluwer.

Harris, Sam, 2005, The End of Faith. Religion, Terror, and the Future of Reason, London: The Free Press.

Haught, James, A., 1990, Holy Horrors. An Illustrated History of Religious Murder and Madness, Amherst, New York: Prometheus Books.

Hirsi Ali, Ayaan, 2007, "Islam's Silent Moderates", in: The New York Times, December 7 .

Hitchens, Christopher, 2007, god is not Great. How Religion Poisons Everything, Boston, New York: Twelve.

Hoffmann, Joseph R., ed., 2006, The Just War and Jihad. Violence in Judaism, Christianity, \& Islam, Amherst, New York: Prometheus Books.

Idziak, Janine Marie, 1979, "Divine Command Morality: A Guide to the Literature", in: Janine Marie Idziak, Divine Command Morality: Historical and Contemporary Readings, New York and Toronto: The Edwin Mellen Press.

Jami, Ehsan, 2007, Het recht om ex-moslim te zijn, Amsterdam: Ten Have.

Juergensmeyer, Mark, 2003, Terror in the Mind of God. The Global Rise of Religious Violence, Third Edition, Revised and Updated, Berkeley/Los Angeles/ London: University of Califonia Press.

Juergensmeyer, Mark, 2008, Global Rebellion: Religious Challenges to the Secular State, from Christian Militias to Al Qaeda, University of Califomia Press, Berkeley: Los Angeles, London.

Karsh, Efraim, 2006, Islamic Imperialism. A History, New Haven and London: Yale University Press.

Lewis, Bernard, 2003, The Crisis of Islam. Holy War and Unholy Terror, London: Weidenfeld \& Nicoison.

Nelson-Pallmeyer, Jack, 2003, Is Religion Killing Us? Violence in the Bible and the Quran, Harrisburg: Trinity Press International.

Plato, Euthyphro.

Selengut, Charles, 2003, Sacred Fury. Understanding Religious Violence, Walnut Creek, Lanham, New York, Toronto, Oxford: Rowman \& Littlefield Publishers.

Spencer, Herbert, 1995, “The Reconciliation", in: Andrew Pyle, ed., Agnosticism. Contemporary Responses to Spencer and Huxley, Bristol: Thoemmes Press, pp. 1-19.

Spencer, Robert, 2003, Onward Muslim Soldiers: How Jihad Still Threatens America and the West, Washington: Regnery Publishing.

Taylor, A.E., 1977 (1926), Plato. The Man and his Work, London: Methuen \& Co. 
Tibi, Bassam, 2008, Political Islam, World Politics and Europe: Democratic Peace and Euro-Yslam versus Global Sihad, London and New York:.Routledge.

Tibi, Bassam, 2009, Euro-Islam: Die Lösung eines Zivilisationskonfliktes, Darmstadt: Primus Verlag,

Warraq, Ibn, ed., 2003, Leaving Islam. Apostates Speak Out, Amherst, New York: Prometheus Books.

Weber, Max, 1966, Siaatssoziologie. Soziologie der rationalen Staatsanstalt und der modernen politischen Parteien und Parlamente, Mit einer Einfuhnung und Erläuterungen herausgegeben von Johannes Winckelmann, Zweite, durchgesehene und ergănzte Auflage, Berlin: Duncker \& Humblot.

Zwemer, Samuel M., 1924, The Law of Apostasy in Islam. Answering the question why there are so few Moslem converts, and giving examples of their moral courage and martyrdom, London, Edingburgh \& New York: Marshall Brothers. 